\title{
Response of herbivorous fishes to crown-of-thorns starfish Acanthaster planci outbreaks. III. Age, growth, mortality and maturity indices of Acanthurus nigrofuscus
}

\author{
Anthony M. Hart ${ }^{1,2, *}$, Garry R. Russ ${ }^{2}$ \\ 'Australian Institute of Marine Science, PMB No. 3, Townsville MC, Queensland 4810, Australia \\ ${ }^{2}$ James Cook University, Townsville, Queensland 4810, Australia
}

\begin{abstract}
Age, growth, mortality and maturity indices of Acanthurus nigrofuscus were examined as part of a larger study investigating a long-term response of herbivorous reef fish to crown-of-thorns starfish (COTS) outbreaks. The principal objective was to compare otolith growth, mean age and size, growth, mortality, size-at-age, size-at-maturity, and age-at-maturity of $A$. nigrofuscus between 2 COTS affected (Yankee, Dip) and 2 non-affected reefs (Bowl, Coil). All reefs were exposed, outer shelf reefs in the central section of the Great Barrier Reef. Additionally, these demographic parameters were also established at 2 mid-she]f reefs (Grub, Centipede). This species is relatively long-lived with the oldest specimen aged at $25 \mathrm{yr}$. Mean age at each reef ranged from 5.4 to $9.5 \mathrm{yr}$, whlle average size ranged from 16 to $12 \mathrm{~cm}$. Mean size and size-at-age was significantly larger on COTS impacted reefs, evidence which supports the hypothesis of a response to increased food resources. There were also significant differences in size-at-age between reefs withın a COTS status. No differences in mortality between reefs was detected, while age-at-maturity was 2 yr at all reefs. Size-at-maturity was 13 to $14 \mathrm{~cm}$ on midshelf reefs Grub and Yankee, in contrast to 10 or $11 \mathrm{~cm}$ on outer shelf reefs Yankee, Bowl, Dip and Coil. Importantly, age validation provided 5 response variables (otolith growth, mean age, somatic growth rates, size-at-age, age-at-maturity) which were used to examine the effects of ecological disturbance on the population biology of reef fish. This further illustrates the usefulness of age validation studies for coral reef fish
\end{abstract}

KEY WORDS: Acanthaster planci Acanthurus nigrofuscus - Age - Growth - Mortality - Response variables

\section{INTRODUCTION}

Studies of the effect of increased food on the abundance and habitat association of herbivorous reef fish have given all possible results (negative, neutral, positive) (Hart et al. 1996). This is because both recruitment and post-recruitment processes interact to drive population dynamics of coral reef fish (Jones 1991). Wass (1987) for example, found a significant increase in abundances of surgeonfish directly correlated with an increased food resource. However, this occurred

\footnotetext{
- Corresponding address: ICLARM Coastal Aquaculture Centre, PO Box 438, Honıara, Solomon Islands.

E-mail:iclarm@ffa.gov.sb
}

only after high recruitment of juvenile surgeonfish. Similarly for damselfish, Jones (1990) showed that following good recruitment years, adult densities may be limited by density-dependent processes. In contrast, Doherty \& Fowler (1994) determined that variable recruitment combined with density-independent mortality were the principal factors controlling the dynamics of some populations of damselfish on the southern Great Barrier Reef (GBR).

After detecting no numerical response of roving herbivorous fish to an increased food resource in the short-term. Williams (1986) postulated that growth rates may be altered in the long-term. An advantage of growth rate as an indicator of response is its dependence on present or recent resource levels and envi- 
ronmental conditions, rather than on previous stages in the life cycle. However, only recently have accurate, simple techniques for interpretation of otolith macrostructure to estimate age and growth rates in coral reef fishes become readily available (Fowler 1990. Ferreira \& Russ 1992, Fowler \& Doherty 1992, Lou 1992). Prior to this, estimates of growth of herbivorous reef fish were derived from modal progression analysis or markrecapture studies (Russ \& St. John 1988), which are prone to subjective interpretation and tagging artefacts (Brothers 1982).

In this study, age, growth rates, mortality and maturity indices of an 'indicator' species, Acanthurus nigrofuscus, were assessed as response variables in determining whether roving herbivorous reef fish responded to increased food (Hart \& Klumpp 1996) following crown-of-thorns starfish (COTS) outbreaks. A. nigrofuscus is a small $(<19 \mathrm{~cm})$ tropical surgeonfish with a worldwide distribution on coral reefs (Robertson 1983, Fishelson et al. 1987) and is particularly abundant on the outer shelfs of the GBR (Russ 1984, Hart et al. 1996). Despite its use as a food source in the South Pacific (P. Dalzell pers. comm.), no published data exist for the key demographic parameters of age, growth and mortality rates, size- and age-atmaturity of this species. Detailed observations do exist on spawning behaviour (Robertson 1983, Myrberg et al. 1988, Fishelson et al. 1987) and reproductive development (Fishelson et al. 1987). In the Red Sea,
A. nigrofuscus is a multiple spawner with reproduction synchronised over a 4 mo spawning season (Fishelson et al. 1987). Prior to Choat \& Axe (in press), ageing studies on acanthurids had focused on the analysis of daily increments in otoliths (Itano 1988); however, this technique is time consuming and usually limited to ageing young fish (Ferreira \& Russ 1993). The presence of annual increments in otoliths has not been validated for any acanthurid, despite this family being among the most abundant and speciesrich taxa of coral reef fish (but see Choat \& Axe in press).

This study was initiated as part of a larger project investigating the response of roving herbivorous reef fish to COTS outbreaks (Hart \& Klumpp 1996, Hart et al. 1996). The main predictive hypothesis is that fish grow more quickly and mature at an earlier age on COTS impacted reefs because of increased food supply (Hart \& Klumpp 1996). Thus the principal objective was to compare otolith growth rate, mean age, mean size, somatic growth rates, mortality rates, sizeat-age, size-at-maturity, and age at maturity of Acanthurus nigrofuscus between COTS affected and nonaffected reefs. Furthermore, since most of these key demographic parameters have not yet been determined for populations of $A$. nigrofuscus, the secondary objective of this study was to determine age, growth, mortality and maturity parameters for this species on 6 reefs within the central GBR.

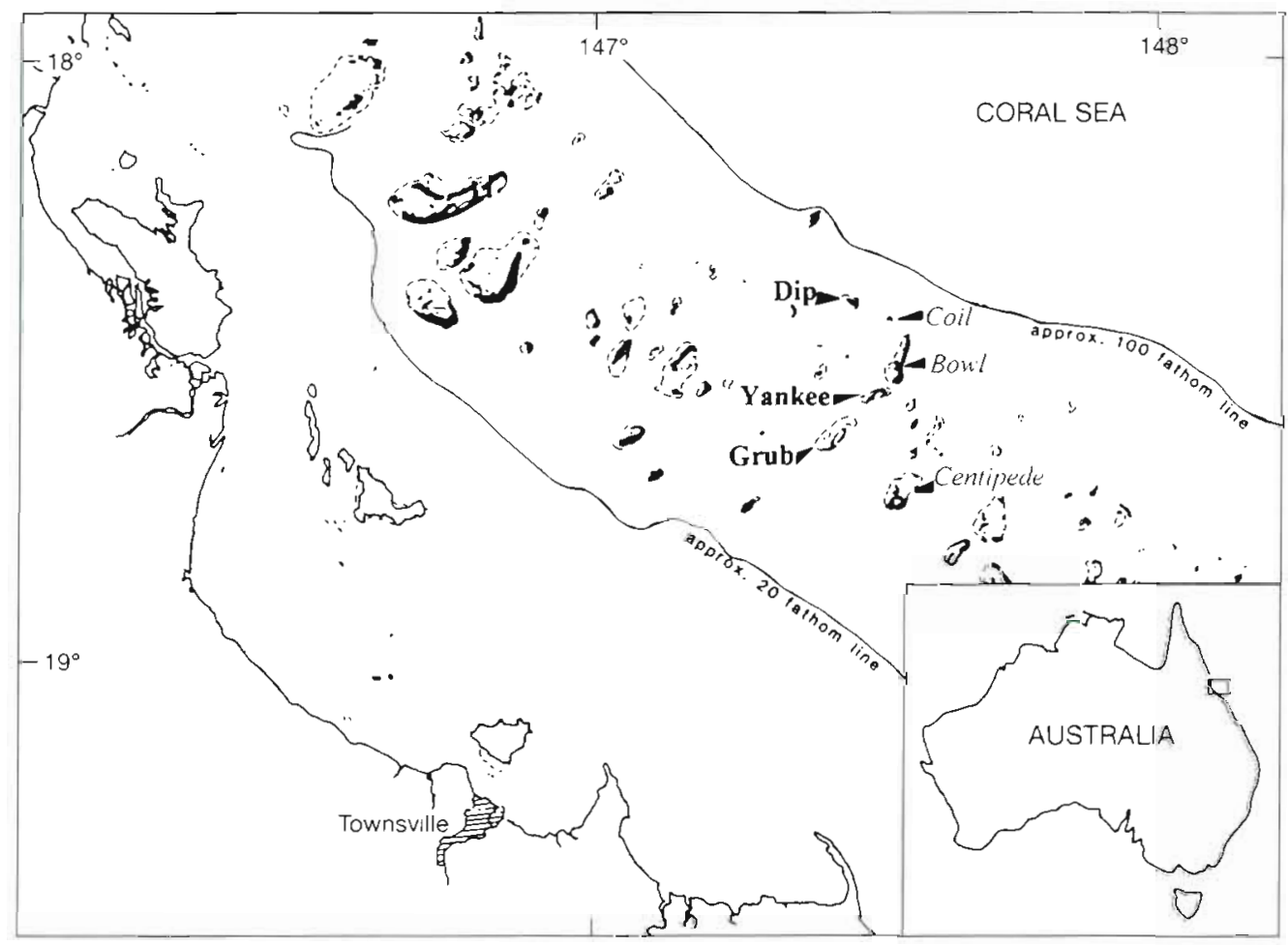

Fig. 1 Map showing reefs considered in this study, and therr general location on the map of Australua 


\section{MATERIALS AND METHODS}

Study sites and field methodology. Specimens were collected from all study reefs (Fig. 1) on 3 separate occasions (April and October 1992 and April 1993) within a year. Spear guns were used at Grub (COTS impacted) and Centipede (non-impacted) reefs where the abundances were not high enough for handnetting. At Yankee, Dip (COTS impacted), Coil and Bowl (non-impacted), monofilament fence nets $(10 \mathrm{~mm}$ mesh size) were used to collect individuals. The general procedure was to set up the nets in the form of a ' $V$ ', using SCUBA, and then to herd the fish into the funnel. Dip nets were used to scoop the fish from the fence nets, after which they were taken to the surface and placed on ice prior to dissection. Most collections were carried out in the front reef slope habitat at a depth of 3 to $7 \mathrm{~m}$. Measurements [fork length $(\mathrm{cm})$ and weights $(\mathrm{g})$ ) and dissections were carried out on board the research vessel. Individuals were sexed according to appearance of gonads, and selected samples preserved in FAACC [a solution of $37 \%$ formaldehyde (10 ml), glacial acetic acid $(5 \mathrm{ml})$, calcium chloride dihydrate $(1.3 \mathrm{~g})$, and tap water $(85 \mathrm{ml})$ ] for histological examination. The head of each specimen was tagged and frozen for later removal of otoliths.

Preparation of otoliths for age determination. Each head was sectioned down the longitudinal axis of the cranium, and the sagittae easily removed from both sides under a low power dissecting microscope. They were washed in fresh water, dried on silk cloth, weighed on a Mettler Balance (Model AC100) to the nearest $0.01 \mathrm{~g}$ and stored dry in glass vials. The length and width of each otolith were measured using a dissecting microscope and an ocular micrometer.

All age determinations were based on transverse sections of the sagittae. Either the left or right sagitta was embedded in Spurr's histological resin, forming a small rectangular block. A $400 \mu \mathrm{m}$ transverse section through the central core of the sagitta was cut using a low speed Buehler Isomet diamond saw. The section was then polished with high grade sandpaper (1200), and 2 sizes of lapping film ( $9 \mu \mathrm{m}, 3 \mu \mathrm{m})$ under dripping water. All sections were examined under a dissecting microscope. The highlighted region in Fig. 2 consistently showed identifiable and readable growth rings and so all counts were made within this region. Transverse sections were photographed under a compound microscope (40x magnification) using colour 200 ASA film.

Validation of age estimates. In May 1992, 300 individuals were tagged on an isolated coral bommie at Dowl rect to validate age estimates of Acanthurns nigrofuscus. Validation was achieved using tetracycline which is metabolised and deposited in the bony tissues (including the otoliths) ultimately forming a time marker

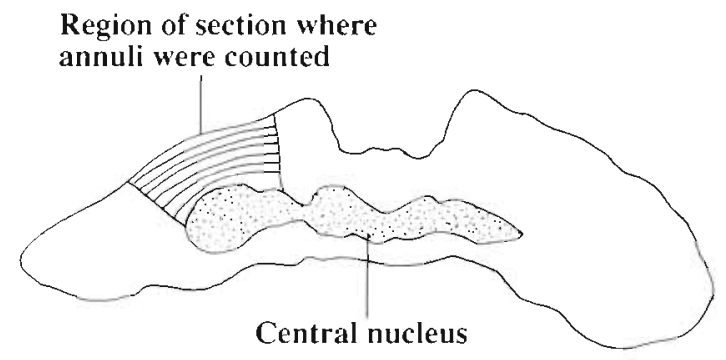

Fig. 2. Acanthurus nigrofuscus. Schematic diagram of a transverse section of a sagitta indicating the area where counts of annuli were made

(Odense \& Logan 1974). The tetracycline was acquired in a solid form and mixed with sterile saline at a concentration of $50 \mathrm{mg} \mathrm{ml}^{-1}$ Individuals were treated at a dosage of $50 \mathrm{mg} \mathrm{kg}^{-1}$ body weight of fish (McFarlane \& Beamish 1987), which was converted to a dosage per length of fish using the following length-weight relationship $(\log W T=1.64 \operatorname{logFL}-0.02)$ where WT = total weight $(g)$ and $F L=$ fork length $(\mathrm{cm})$. Fish were collected and initially placed in a submerged holding tank, after which they were transferred a few at a time to the boat, measured (FL), injected with the required dosage of tetracycline, and released. Tetracycline was injected through the skin, under the mid-lateral, post-pectoral scales into the coelomic cavity. A $1.0 \mathrm{~mm}$ syringe with a 26 gauge needle was used for this operation. All specimens were tagged externally with fine $\mathrm{T}$-bar anchor tags inserted in the dorsal musculature between the 2nd and 3rd dorsal spines. In April 1992, 1 specimen was recaptured after an 11 mo period, and a further 4 specimens were recaptured in November 1993 after 18 mo at liberty. Sagittae were examined under a compound microscope with an ultraviolet light source to identify the fluorescent band resulting from the treatment with tetracycline.

Evaluation of response variables. This involved a comparison of 8 variables from COTS impacted (Yankee, Dip) and non-impacted (Bowl, Coil) reefs. Details on variables, analyses and results of comparison are shown in Table 1 Data from mid-shelf reefs of Grub (impacted) and Centipede (non-impacted) were not included in the analyses because of the different sampling technique used and the confounding effect of cross-shelf positions.

Growth and mortality rates. The number of otoliths used to establish growth and mortality rates in Acanthurus nigrofuscus were: Centipede ( $\mathrm{n}=57$ ); Grub ( $\mathrm{n}=$ 69); Yankee $(n=87)$; Bowl $(n=106)$, Coil $(n=95)$; Dip $(\mathrm{n}=111)$ Senmetric mean regressions were obtained for the otolith and fish dimensions (Ricker 1973), and analysis of covariance (ANCOVA) was used to test for differences in otolith growth rates between reefs. Von 
Bertalanffy growth functions (VBGF) were fitted to the length-at-age data using non-linear parameter estimation procedures, and the growth parameters $K_{1} L_{c}$ and $t_{0}$ estimated with standard errors. Analysis of residual sums of squares (ARSS; Chen et al. 1991) was used to compare VBGFs between Yankee, Bowl, Dip and Coil. Age-based catch curves (Pauly 1984) were used to estimate natural mortality $(Z)$, which is the slope of the regression of $\log _{e}$ frequency against age. $Z$ (slopes) were compared between Yankee, Dip, Coil and Bowl by ANCOVA (Zar 1984).

Size-at-age. The most direct way of assessing sizeat-age was to divide the data into separate age groups ( 1 and 2,3 and $4, \ldots, 13+$ ) and compare mean FL between reefs. Two ages were pooled to obtain adequate replication, and size at each age group was assessed with a 2 -factor analysis of variance (ANOVA) (COTS status, Reef). All factors were fixed, although reef was nested within COTS, hence no interaction was present. Tukey's post-hoc pair-wise comparisons were carried out where applicable. The assumptions of normality and homoscedascity were examined and data transformed to $\ln (x+1)$.

Size and age at first maturity. Individuals were classified into male and female via macroscopic examination of the gonads, sensu Fishelson et al. (1987). Initial estimates showed no difference in mean size or age of males and females, so they were subsequently grouped together for analysis. Percent frequencies were calculated for mature males and females, and age and size at first maturity was defined when $50 \%$ of the examined individuals had undergone maturation. Observations for age-at-maturity are grouped into 2 age classes to provide sufficient replication and for ease of interpretation. Number of individuals examined for size- and age-at-maturity respectively were: Grub, 47; Centipede, 40; Yankee, 74; Bowl, 81; Dip, 72; Coil, 75 .

\section{RESULTS}

\section{Validation of annual growth increments}

The formation of annual growth increments in the otoliths of Acanthurus nigrofuscus was assessed according to 3 criteria (Fowler \& Doherty 1992).

Criterion 1. Otoliths must display an internal structure of increments

When observed under reflected light, transverse sections of the sagittae of Acanthurus nigrofuscus (Fig. 3) showed a pattern of alternating translucent (transmit- ted light-light) and opaque zones (transmitted lightdark) similar to that recently observed in other coral reef fish species (Fowler 1990, Ferreira \& Russ 1992, 1993, Fowler \& Doherty 1992, Lou 1992). This internal structure was consistent across otoliths examined from 6 different reefs

Criterion 2: Otolith structure must be related to some regular time scale

There were 5 recaptures of Acanthurus nigrofuscus, and the position of the tetracycline band was in the translucent zone of each (Fig. 4). All individuals recaptured in November after 18 mo at liberty showed a distinct opaque zone on the otolith margin, whereas those recaptured in April after 11 mo at liberty had a translucent margin. These facts suggest that the annulus is formed once per year during spring and summer.

Criterion 3: Otoliths must grow throughout the lives of the fish at a perceptible rate

This was assessed by determining the relationship between otolith size and fish length at each reef. Firstly, there was a significant positive relationship between FL and sagittal length at all reefs (Fig. 5). At Yankee, Bowl, Dip, and Coil, where an adequate size range was sampled, 62 to $74 \%$ of the variation in sagittal length was explained by the variation in FL (Fig. 5). For Grub and Centipede, $r^{2}$ values of 0.16 and 0.4 , respectively, were abtained. To corroborate these results, geometric mean regressions and $r^{2}$ values were established between age (from counting of opaque bands) and sagittae weight. Again, significant positive relationships were obtained, with $\mathrm{r}^{2}$ values ranging from 0.51 at Centipede reef to 0.87 at Dip reef (Fig. 6). Furthermore, a significant difference in slopes of the regressions was detected $(\mathrm{df}=5.371 ; F=2.85 ; \mathrm{p}<$ 0.05). Tukey's test showed that Coil and Dip reefs had a significantly lower slope than Bowl, with the other reefs grouping together. Hence, for a given age, otoliths from Coil and Dip were lighter than those from Bowl, indicating a slower rate of otolith growth.

\section{Evaluation of response of Acanthurus nigrofuscus to COTS outbreaks}

Significant differences in mean size, growth rates, and size-at-age were detected between COTS affected and non-affected reefs (Table 1). No differences in otolith growth, mean age, mortality rates, size-atmaturity or age-at-maturity were found. 


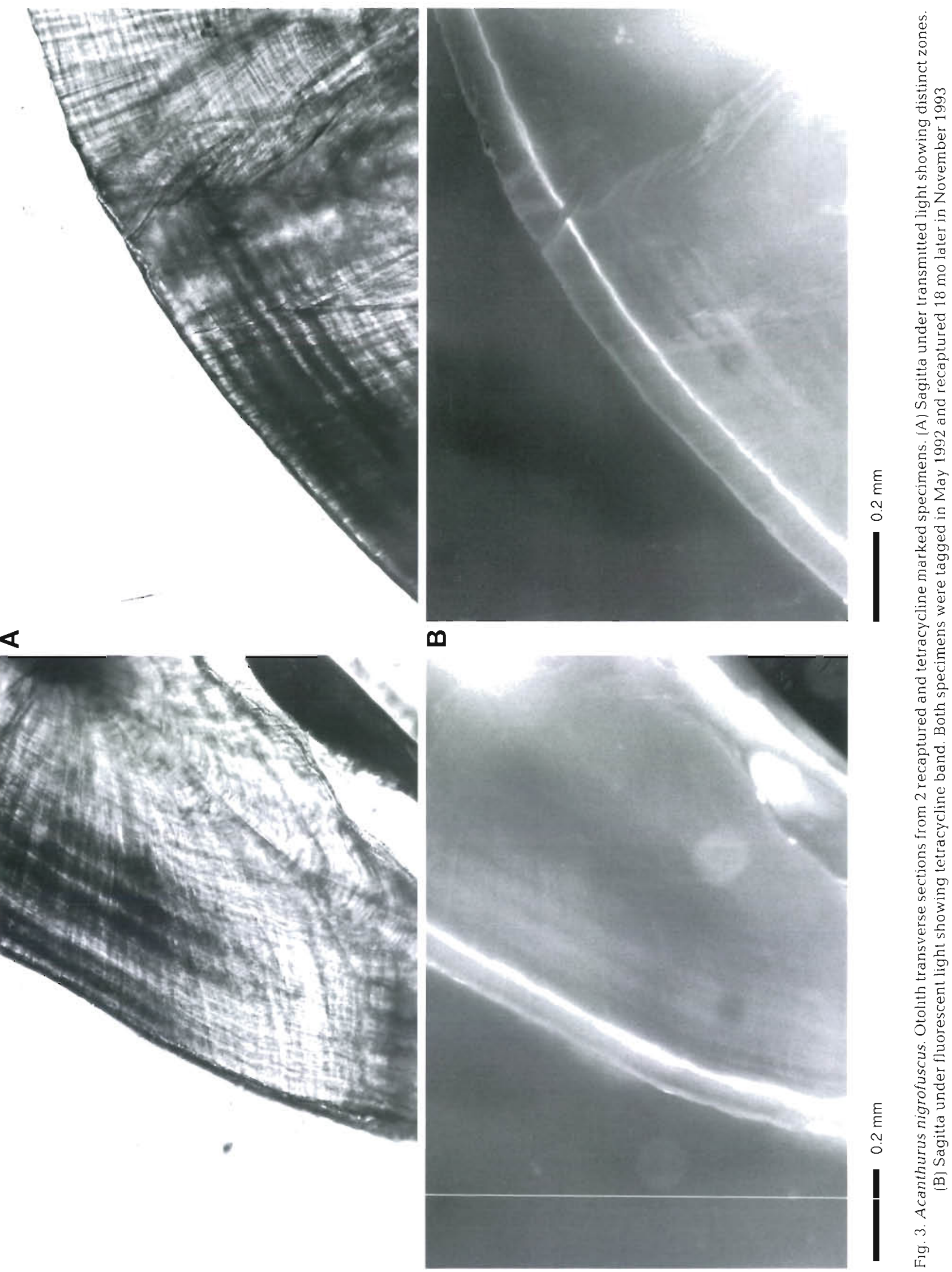




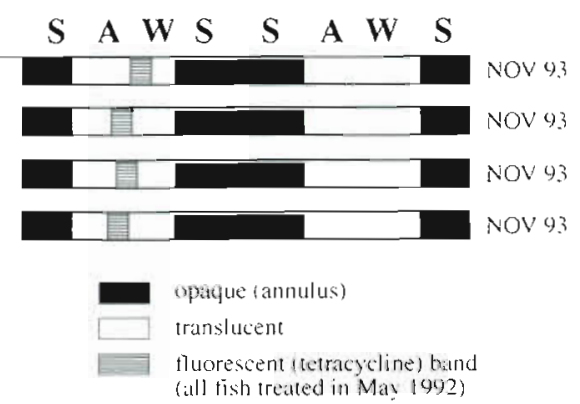

Fig. 4. Acanthurus nigrofuscus. Schematic diagram indicating the location of the tetracycline band within the alternating opaque and translucent bands in the sagittae of recaptured specimens. Seasons (summer, autumn, winter, spring) are shown across the top

\section{Growth of Acanthurus nigrofuscus}

Von Bertalanffy growth curves and equations describing growth in Acanthurus nigrofuscus from 6 reefs are shown in Fig. 7. The 2 mid-shelf reefs, Grub (impacted) and Centipede (non-impacted), had similar values of $L_{\infty}$. Centipede however exhibited a very large $K$ value of 1.72 in comparison with 0.38 at Grub (Table 2). This was due to the three $1 \mathrm{yr}$ old individuals at Centipede being much smaller than the other age classes which were similar in size.

A significant difference in growth rates was detected between reefs $(\mathrm{df}=3,368 ; F=49.15 ; \mathrm{p}<0.001)$. Analysis of size-at-age (Table 2 ) reveals that for these age groups, Coil has the smallest individuals, followed by Dip, Bowl and Yankee in ascending order. Furthermore, mean size of Acanthurus nigrofuscus was significantly larger on impacted reefs for 6 out of 7 age groups (Table 2). Mean age $( \pm 95 \% \mathrm{CL})$ in years was $9.5 \pm 1.3$ at Grub, $8.7 \pm 1.8$

Table 1 . Summary of results for comparison of 8 response variables from COTS impacted and non-impacted reefs. With the exception of otolith growth, analysis was restricted to Yankee, Dip (impacted), Bowl and Coil (non-impacted). VB: Von Bertalanffy

\begin{tabular}{|lll|}
\hline Variable & Test & Result \\
\hline Otolith growth rate & ANCOVA & No difference $F_{(1,212)}=0.38$ \\
Mean age & ANOVA & No difference $; F_{(1,362)}=0.2$ \\
Mean fork length & ANOVA & Significant difference; $F_{(1,346)}=64.8$ \\
VB growth rates & ARSS & Significant difference; $F_{(3,392)}=12.7$ \\
Mortality rates & ANCOVA & No difference; $F_{(1,51)}=0.37$ \\
Size-at-age & ANOVA & Significant difference; see Table 3 \\
Size-at-maturity & Gonad staging & No difference \\
& & Impacted $10-11 \mathrm{~cm}$ \\
& & Non-impacted $10-11 \mathrm{~cm}$ \\
Age-at-maturity & Gonad staging & No difference \\
& & Impacted $2 \mathrm{yr}$ \\
& & Non-impacted $2 \mathrm{yr}$ \\
\hline
\end{tabular}
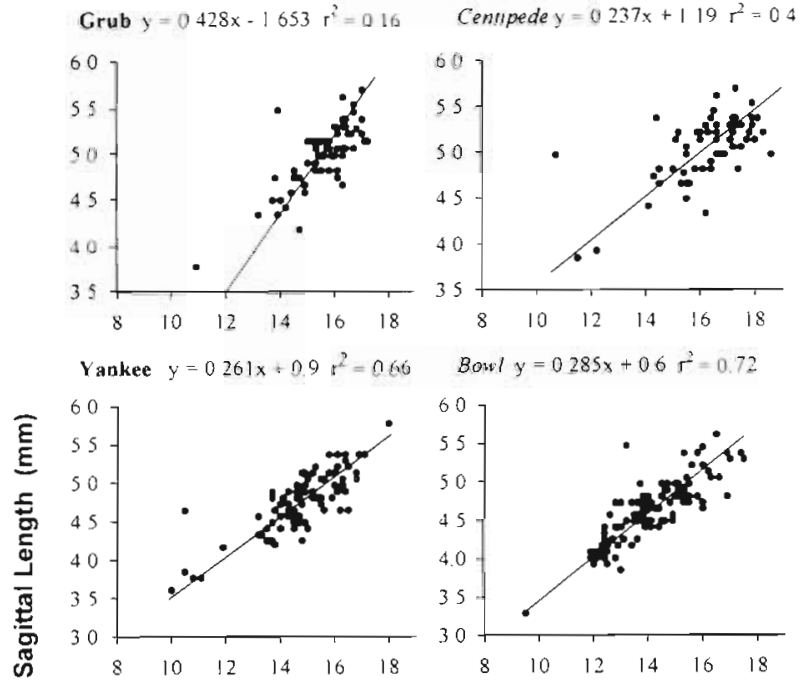

Dip $y=0272 x+088 \quad r^{2}=074$

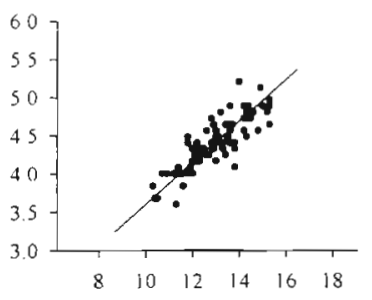

Conl $y=0305 x+048 r^{2}=062$

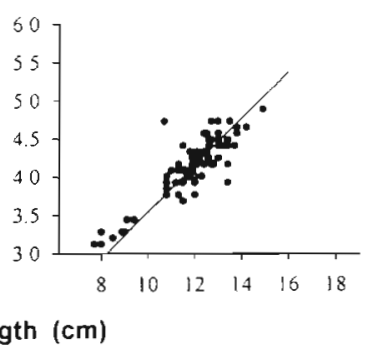

Fig. 5. Relationship between fork length and sagittal length at COTS impacted (bold) and non-impacted (italics) reefs

at Centipede, $6.2 \pm 0.9$ at Yankee, $6.6 \pm 1$ at Bowl, $5.4 \pm$ 1.2 at Dip and $6.2 \pm 1.1$ at Coil.

A comparison of length and age frequencies of Acanthurus nigrofuscus from the 6 study reefs is shown in Fig. 8. There is a distinct shift in size frequency distribution from the mid-shelf reefs of Grub and Centipede to the outer shelf reefs of Dip and Coil. A similar but less distinct trend occurs for age frequency distribution.

\section{Mortality rates of Acanthurus nigrofuscus}

For the mid-shelf reefs, the total rate of mortality $Z( \pm \mathrm{SE}$ ) was $0.07 \pm 0.038$ at Centipede and $0.26 \pm 0.11$ at Grub, representing an annual survival of 93 and $77 \%$ respectively (Fig. 9). Estimates of $Z$ from Yankee (impacted) and Bowl (nonimpacted) were $0.15 \pm 0.04$ and $0.19 \pm$ 0.023 respectively. Similar estimates were obtained from Dip (impacted), 
Grub $y=141 x+950 \mathrm{r}^{2}=079$
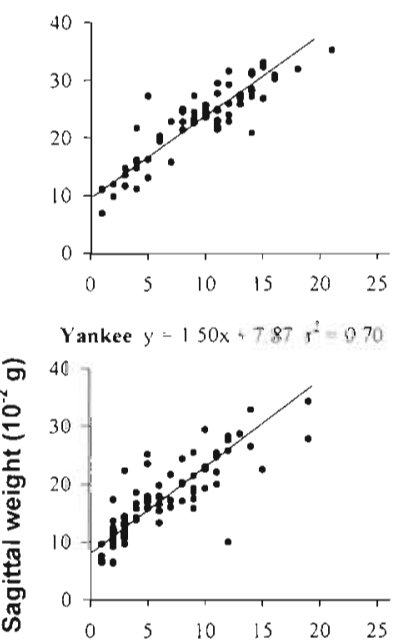

Dip $y=129 x+647 r^{2}=087$

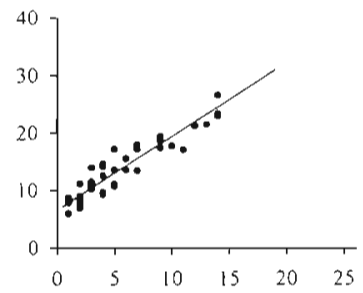

Age (years)

Fig. 6. Relationship between sagitta weight and age. Other details as in Fig. 5

$0.2 \pm 0.045$, and Coil (non-impacted), $0.18 \pm 0.046$. No difference in mortality rates between Yankee, Bowl, Dip, and Coil was detected ( $\mathrm{df} 3,45 ; F=0.37$; $p>0.05$ ).

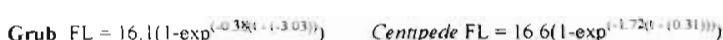
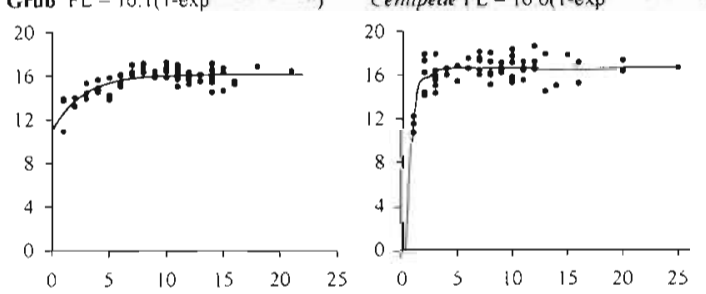

Yankee $F L=158\left(1-\exp ^{1.045(1-(-2) 20(0)))}\right.$

Bow/ FL $=156\left(1-\exp ^{(-0.191-1-005)) ;}\right)$
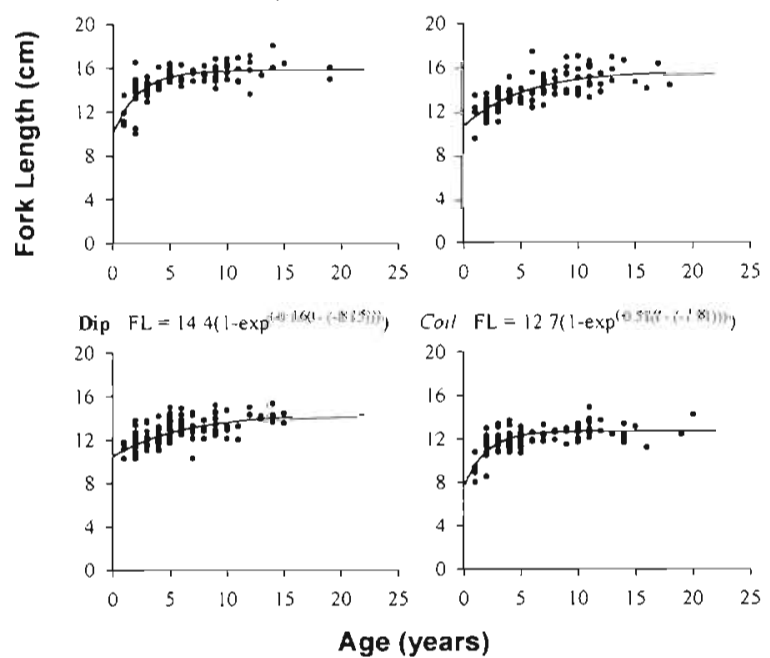

Fig. 7. Acanthurus nigrofuscus. Von Bertalanffy growth functions for fish at 6 reefs. Other details as in Fig. 5

\section{Size and age at first maturity}

Age of first reproduction (50\% of individuals reproductive) for Acanthurus nigrofuscus (male and female) was 2 yr at all reefs (Fig. 10). Size at first reproduction

Table 2. Results of ANOVAs comparing size-at-age (cm and years) at impacted (bold) and non-impacted (italics) reefs. Two age groups are pooled in each instance to provide adequate replication. All data $\ln (x+1)$ transformed. For Tukey's test, groups connected by a line are not significantly different

\begin{tabular}{|c|c|c|c|c|c|c|c|c|}
\hline \multirow{2}{*}{$\begin{array}{l}\text { Age }(y r) \\
1-2\end{array}$} & \multirow{2}{*}{$\begin{array}{l}\text { COTS effect } \\
\text { Significant difference } \\
\mathrm{df}=1,66 ; F=10.4\end{array}$} & \multicolumn{3}{|c|}{ Mean fork length $(\mathrm{cm})$} & \multicolumn{4}{|c|}{ Tukey's test - Reef effect } \\
\hline & & $\begin{array}{l}\text { Significant difference } \\
\mathrm{df}=2,66 ; F=12.3\end{array}$ & $\begin{array}{c}\text { Impacted } \\
12.4\end{array}$ & $\begin{array}{c}\text { Non-impacted } \\
11.3\end{array}$ & $\begin{array}{l}\text { Coil } \\
10.6\end{array}$ & $\begin{array}{l}\text { Dip } \\
11.5\end{array}$ & $\begin{array}{c}\text { Bowl } \\
12.1\end{array}$ & $\begin{array}{c}\text { Yankee } \\
13.3\end{array}$ \\
\hline $3-4$ & $\begin{array}{l}\text { Significant difference } \\
\text { df }=1,97 ; F=24.3\end{array}$ & $\begin{array}{l}\text { Significant difference } \\
\mathrm{df}=2,97 ; F=44.3\end{array}$ & $\begin{array}{l}\text { Impacted } \\
13.3 \\
\end{array}$ & $\begin{array}{c}\text { Non-impacted } \\
12.4 \\
\end{array}$ & $\begin{array}{l}\text { Coil } \\
11.9\end{array}$ & $\begin{array}{l}\text { Dip } \\
12.3\end{array}$ & $\begin{array}{c}\text { Bowl } \\
13.0\end{array}$ & $\begin{array}{c}\text { Yankee } \\
14.3\end{array}$ \\
\hline $5-6$ & $\begin{array}{l}\text { Significant difference } \\
\mathrm{df}=1,71 ; F=41.5\end{array}$ & $\begin{array}{l}\text { Significant difference } \\
\mathrm{df}=2.71 ; F=41.0\end{array}$ & $\begin{array}{c}\text { Impacted } \\
14.2 \\
\end{array}$ & $\begin{array}{c}\text { Non-impacted } \\
12.8\end{array}$ & $\begin{array}{l}\text { Coil } \\
12.0 \\
\end{array}$ & $\begin{array}{l}\text { Dip } \\
13.1\end{array}$ & $\begin{array}{l}\text { Bowl } \\
13.7\end{array}$ & $\begin{array}{c}\text { Yankee } \\
15.3\end{array}$ \\
\hline $7-8$ & $\begin{array}{l}\text { Significant difference } \\
\mathrm{df}=1,34 ; F=5.5\end{array}$ & $\begin{array}{l}\text { Significant difference } \\
\mathrm{d} f=2,34 ; F=25.4\end{array}$ & $\begin{array}{c}\text { Impacted } \\
14.2 \\
\end{array}$ & $\begin{array}{c}\text { Non-impacted } \\
13.4\end{array}$ & $\begin{array}{l}\text { Coil } \\
12.5 \\
\end{array}$ & $\begin{array}{l}B \\
12.9\end{array}$ & $\begin{array}{c}\text { Bowl } \\
14.4\end{array}$ & $\begin{array}{c}\text { Yankee } \\
15.4\end{array}$ \\
\hline $9-10$ & $\begin{array}{l}\text { Significant difference } \\
\mathrm{df}=1,47 ; F=10.8\end{array}$ & $\begin{array}{l}\text { Significant difference } \\
\mathrm{df}=2,47 ; F=35.8\end{array}$ & $\begin{array}{c}\text { Impacted } \\
14.7 \\
\end{array}$ & $\begin{array}{c}\text { Non-impacted } \\
13.8 \\
\end{array}$ & $\begin{array}{l}\text { Coil } \\
12.6 \\
\end{array}$ & $\begin{array}{l}\text { Dip } \\
13.6\end{array}$ & $\begin{array}{c}\text { Bowl } \\
15.0\end{array}$ & $\begin{array}{c}\text { Yankee } \\
15.7\end{array}$ \\
\hline $11-12$ & $\begin{array}{l}\text { No difference } \\
\text { dî }=1,2 \overrightarrow{2} ; F=2.3\end{array}$ & $\begin{array}{l}\text { Significant difference } \\
\text { ùi }-2,27 ; T-3.8\end{array}$ & $\begin{array}{l}\text { Impacted } \\
150 \\
\end{array}$ & $\begin{array}{c}\text { Non-impacted } \\
1.2 .2\end{array}$ & $\begin{array}{l}\text { Coil } \\
133 \\
\end{array}$ & $\begin{array}{l}\text { Dip } \\
13 \hbar\end{array}$ & $\begin{array}{c}\text { Bowl } \\
14.9\end{array}$ & $\begin{array}{c}\text { Yankee } \\
15.7\end{array}$ \\
\hline $13+$ & $\begin{array}{l}\text { Significant difference } \\
\mathrm{df}=1,28 ; F=14.2\end{array}$ & $\begin{array}{l}\text { Significant difference } \\
\mathrm{df}=2,28 ; F=21.9\end{array}$ & $\begin{array}{c}\text { Impacted } \\
15.2 \\
\end{array}$ & $\begin{array}{c}\text { Non-impacted } \\
14.0\end{array}$ & $\begin{array}{l}\text { Coil } \\
12.6\end{array}$ & $\begin{array}{l}\text { Dip } \\
14.3\end{array}$ & $\begin{array}{c}\text { Bowl } \\
15.4\end{array}$ & $\begin{array}{c}\text { Yankee } \\
16.1\end{array}$ \\
\hline
\end{tabular}




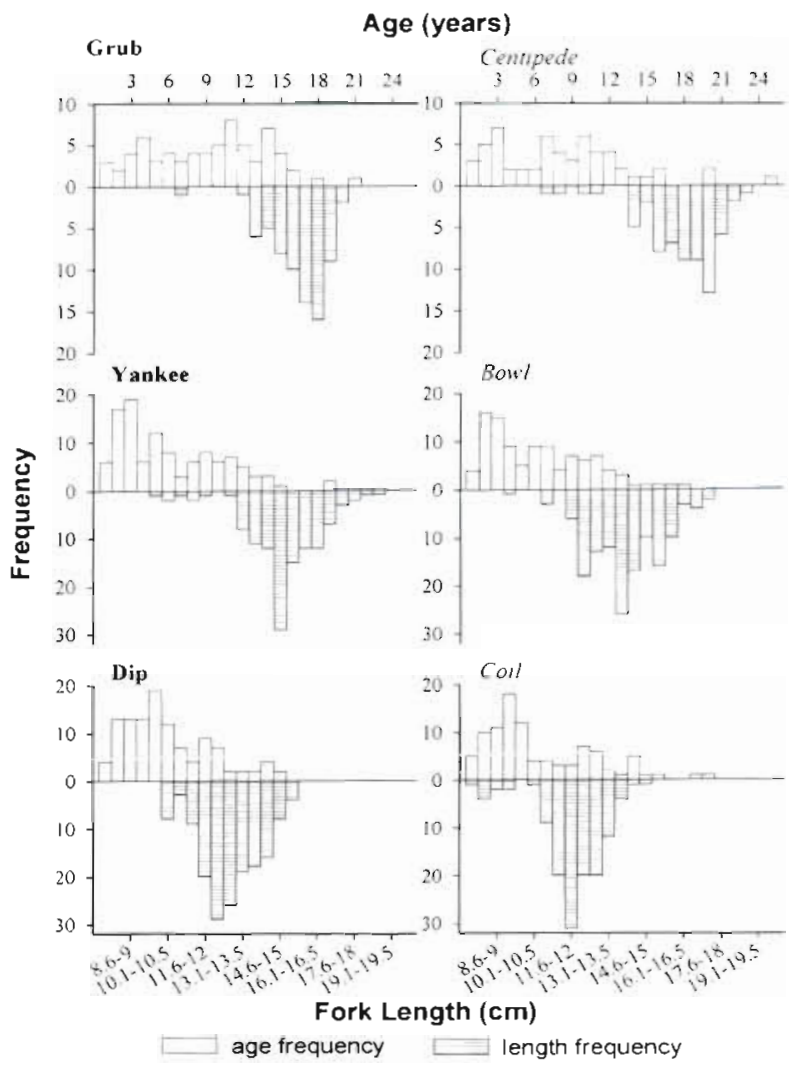

Fig. 8. Acanthurus nigrofuscus. Comparison of length and age frequency distributions. Age classes are individual years, while length classes are $0.5 \mathrm{~cm}$. increments. Other details as in

Fig. 5

on Grub and Centipede was in the range 13 to $14 \mathrm{~cm}$ (Fig 11); however data were scant and results preliminary. At Yankee, Bowl, Dip and Coil, size at first maturity was slightly smaller at 10 to $11 \mathrm{~cm}$ (Fig. 11).

\section{DISCUSSION}

This study is the first to establish the crucial demographic parameters of age, growth, mortality, size- and age-at-maturity of Acanthurus nigrofuscus. Furthermore, these were estimated for 6 different reefs in the central GBR. This study, and that of Choat \& Axe (in press), are the first instances of age determination using otolith annual increments to be carried out for the family Acanthuridae. As such it represents a valuable contribution to the biology of surgeonfish on coral reefs.

\section{Age validation}

All 3 criteria for otoliths to be used as age recorders (Fowler \& Doherty 199 2 ) were fulfilled. Intorpretable internal structure was risible in otoliths from all reefs.

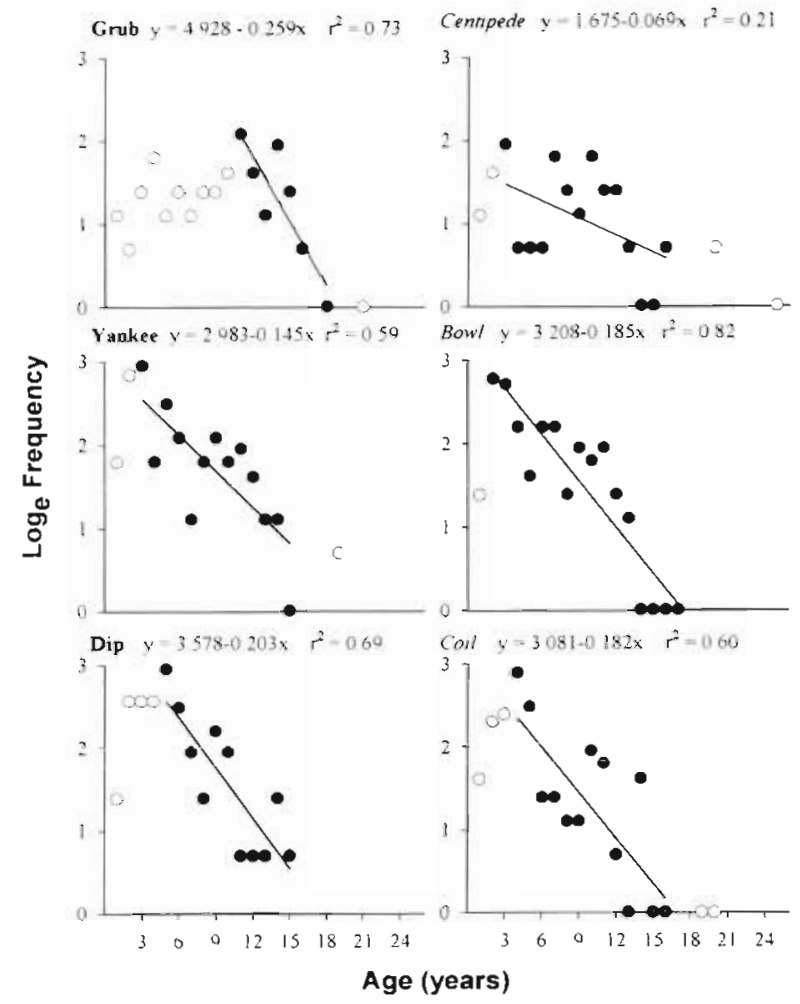

Fig. 9. Acanthurus nigrofuscus. Mortality equations islope $=$ $\mathrm{Zl}_{i}$ closed circles are data points used in the regression equatuon; open points were not used (see Pauly 1984 for criteria used in selecting points for estimation of $Z$ ). Other detals as in Fig. 5
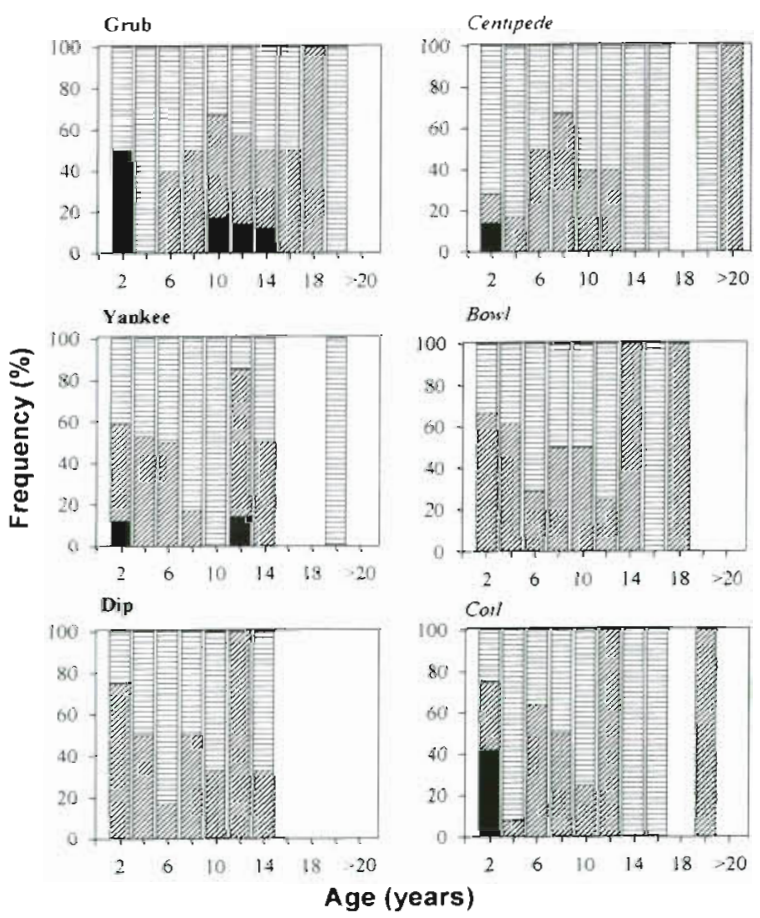

Age (years)

immature שxila mature males $\rightleftharpoons$ mature females

1.d. 10. Acanthurus nigrofuscus. Age-at-maturity of fish at 6 reefs. Other details as in Fig. 5 

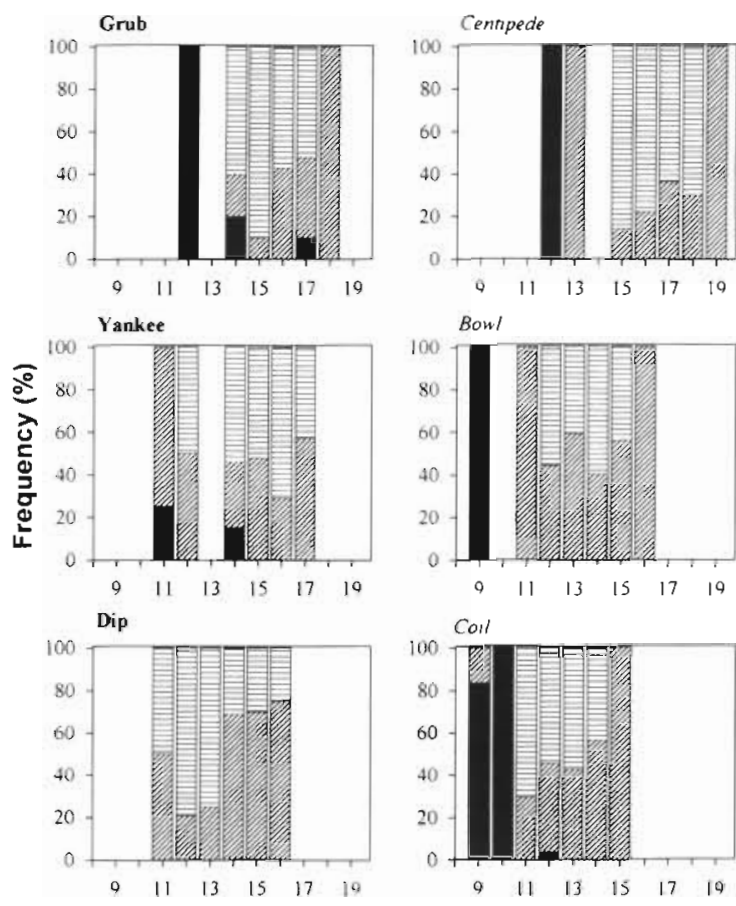

Fork Length $(\mathrm{cm})$

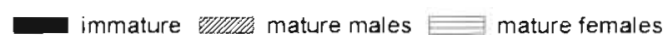

Fig. 11 Acanthurus nigrofuscus. Size-at-maturity of fish at 6 reefs. Other details as in Fig. 5

Furthermore, the use of tetracycline as a 'time-stamp' provided an unambiguous demonstration that increments were formed on an annual basis, with the annulus (opaque zone) probably being laid down between September and December, the spring-summer months, when the fish are likely to be spawning (Fishelson et al. 1987). Furthermore, all specimens collected from all reefs during October 1992 had mature, fully developed gonads. Finally, it was demonstrated that otoliths grow proportionately with annual increments, supported by the fact that the heaviest otolith came from the oldest fish at 25 yr These data are in agreement with Choat \& Axe (in press) who demonstrated life spans of 30 to $45 \mathrm{yr}$ in 10 larger species of acanthurid and a similar time of annulus formation. Thus, unfished stocks of acanthurid fishes on coral reefs are long-lived, with rapid initial growth to maximum size in 3 or $4 \mathrm{yr}$, followed by long periods of asymptotic growth (Choat \& Axe in press)

The recent validation of annuli within the otoliths of acanthurids is further evidence that coral reef fish can be aged accurately using interpretation of otolith macrostructure (Fowler 1990. Farroira \& Russ 1992. 1993, Fowler \& Doherty 1992, Lou 1992). The importance of age validation is emphasised here from the point of view of a new suite of variables to be used in assessing the effects of environmental disturbance or impact on coral reefs. It provided 5 response variables (otolith growth, mean age, somatic growth rates, sizeat-age, and age-at-maturity) which were tested as evidence for population response to increased food availability. Furthermore these types of studies are simultaneously providing essential biological information required to manage fish stocks on a reef-by-reef basis.

\section{Evaluation of response variables}

Significant differences in growth rates, mean size, and size-at-age were detected in a comparison of 2 impacted and 2 non-impacted reefs. Both mean size and size-at-age were significantly greater on COTS impacted reefs. These results are consistent with the hypothesis of there being more food on impacted reefs, which is supported by a far higher abundance of algal turfs (Hart \& Klumpp 1996). As such they comprise the first evidence of a response of herbivorous fish to COTS outbreaks. More importantly, with the exception of Grub and Centipede, which were not included in the analysis, the reefs are all outer shelf reefs with similar exposure and orientation to oceanographic conditions. Grub and Centipede, being mid-shelf reefs, show very different age and size structure from the outer shelf reefs; however, this difference may be exacerbated by the selectivity of the sampling technique and smaller sample sizes.

\section{Growth of Acanthurus nigrofuscus}

Evidence of different reef-specific growth rates is shown in size-at-age estimates (Table 2) For each age group, Coil had the smallest sizes, followed by Dip, Bowl, and Yankee in that order This is corroborated by otolith growth rates at Coil, which were significantly slower than on the other reefs. A general trend is that $L_{\infty}$ of Acanthurus nigrofuscus is attained in 4 to 6 yr which is typical for small tropical fishes (Buesa 1987). Hence this species is both fast-growing and long-lived with the vast majority of individuals probably approaching $L_{\mathrm{c}}$. Obvious factors contributing to growth rates would be food supply and physical environment. Coil was exceptional among these reefs, having the lowest turf algal cover, highest feeding rates (Hart \& Klumpp 1996), slowest growth and smallest sizes. However, on Bowl, only $3 \mathrm{~km}$ to the south, which has a similar exposure, orientation and COTS status, A. nigrofuscus had significantly lower feeding (Hart \& Klumpp 1996), higher growth rates, and larger sizes. 
Table 3. Acanthurus nigrofuscus. Comparison of total mortality rates $(Z$ ) estimated from 4 different methods. Hoenig (1984): $\ln Z=1.44-0.984 \ln t_{\max }$ where $t_{\max }$ is the maximum observed age (yr). Beverton \& Holt $(1957): Z=K\left(L_{w}-\bar{L}\right)\left(\bar{L}-L^{\prime}\right)$ where $L^{\prime}$ is length $(\mathrm{cm})$ at which fish are fully exploited by the fishing gear, and $\bar{L}$ is the mean length $(\mathrm{cm})$ of all fish greater than $L^{\prime} Z_{\mathrm{p} C}=Z$ calculated from catch curve predicted from VBGF; $Z_{c c}=Z$ calculated from catch curve of observed age frequencies

\begin{tabular}{|c|c|c|c|c|c|c|c|}
\hline Reef & $t_{\max }$ & $L^{\prime}$ & $\bar{L}$ & $\frac{Z}{\text { (Hoenig 1984) }}$ & $\begin{array}{l}Z \text { (Beverton } \\
\& \text { Holt 1957) }\end{array}$ & $\begin{array}{c}Z_{\mathrm{PC}} \\
\text { (this study) }\end{array}$ & $\begin{array}{c}Z_{C C} \\
\text { (this study) }\end{array}$ \\
\hline Grub & 21 & 14 & 15.8 & 0.21 & 0.20 & 0.10 & 0.26 \\
\hline Centipede & 25 & 14 & 16.4 & 0.18 & 0.83 & & 0.07 \\
\hline Yankee & 19 & 13 & 15 & 0.23 & 0.72 & 0.60 & 0.15 \\
\hline Bowl & 18 & 12 & 14.1 & 0.25 & 0.60 & 0.21 & 0.19 \\
\hline Dip & 15 & 11 & 13 & 0.29 & 0.45 & 0.24 & 0.20 \\
\hline Coil & 20 & 10 & 12.2 & 0.22 & 0.56 & 0.38 & 0.18 \\
\hline
\end{tabular}

\section{Mortality}

Total mortality rates obtained from empirical techniques (Beverton \& Holt 1957, Pauly 1980, Hoenig 1984) are compared with those estimated from the observed $\left(Z_{\mathrm{CC}}\right)$ age structure, and predicted $\left(Z_{\mathrm{PC}}\right)$ age structure from the VBGF (Table 3). Hoenig's (1984) empirical formula, based on maximum observed age, gave very similar estimates to $Z_{C C}$. Estimates of $Z_{P C}$ were too high on Yankee and Coil. This was caused by the age distribution constructed from the age-length key being different from the observed age distribution, the difference resulting from (1) large size-at-age variability, and (2) a substantial proportion of individuals having lengths $>L_{\infty}$. At Yankee and Coil, $25 \%$ of all individuals were larger than $L_{\infty}$. Pauly (1984) stated that $L_{\infty}$ is generally $L_{\max } / 0.95$; however, this does not hold true for these unexploited populations of Acanthurus nigrofuscus. Moreover, although these estimates are from a relatively small sample of aged fish, Kimura (1977) argued that this is in many cases more appropriate than $Z$ estimated from age-length keys, which can result in biased mortality estimates. This occurred in our study, at least on Yankee and Coil. The overall rate of $Z$ and hence natural mortality $(M)$ is 0.2 and this is in agreement with data from other tropical fish species (Pauly 1980).

\section{Age- and size-at-maturity}

Sexual maturity in Acanthurus nigrofuscus appears to be age-dependent rather than length-dependent. While age-at-maturity was 2 yr at all reefs, size-atmaturity was 2 to $4 \mathrm{~cm}$ greater on Grub and Centipede. as opposed to Yankee, Dip, Bowl and Coil. For example, a $12.4 \mathrm{~cm}$ individual at Coil was $19 \mathrm{yr}$ of age, while at Grub and Centipede an individual of this size was unlikely to be sexually mature and hence $<2$ yr of age. Data on age-at-maturity of other coral reef fish species are scant, although Ferreira (1993) showed that the inshore coral trout on the GBR also matured at 2 yr.

\section{Usefulness of response variables}

The detection of inter-reefal differences in growth rates, mean size and size-at-age exemplifies the usefulness of these response variables in assessing the effects of environmental disturbance on reef fish. Evaluation of abundances (Bohnsack 1983, Lassig 1983, Walsh 1983) will always be subject to high variability and debate on the underlying causes (Jones 1991. Fowler \& Doherty 1994). Once age validation has been completed, growth rates, size-at-age, and age-atmaturity are relatively simple to assess. Compare this to the cost of obtaining growth rates from modal progression or mark-recapture studies, both of which are sensitive to high individual variability in growth rates (Sainsbury 1980). However, the key to age-related parameters being used as response variables in disturbance assessment is that the methodological processes in ageing and age validation become widely explored, accepted and available. One of the first processes which needs clarifying is how to count the first 2 annuli following settlement. These are the hardest rings to identify because of their diffuseness, yet are critical if the fish are reaching maturity at a young age.

Acknowledgements. This project was greatly assisted by Dr David Klumpp of AIMS whose generosity with the allocation of research vessel time allowed the project to eventuate This project was funded by a COTSREC (Crown-of-Thorns Starfish Research Committee) PhD scholarship to A.M.H., administered by the Great Barrier Reef Marine Park Authority, with logistical support from AIMS. The authors thank the many volunteer research assistants, principally Rod Forbes and Dave Hocking. Finally, special thanks to the crew of the RV 'Harry Messel', who made the field excursions safe and enjoyable, and to the anonymous referees for their pertinent comments. This is Contribution No. 769 from the Australian Institute of Marne Science. 


\section{LITERATURE CITED}

Beverton RJH, Holt SJ (1957) On the dynamics of exploited fish populations. Fish Invest Ser II 19:533

Bohnsack JA (1983) Resiliency of reef fish communities in the Florida Keys following a January 1977 hypothermal fish kill. Environ Biol Fish 9(1):41-53

Brothers EB (1982) Ageing reef fishes. In: Huntsman GR, Nicholson WR, Fox WW (eds) The biological bases for reef fishery management. NOAA Nat Mar Fish Serv Tech Memo, US Dept Commerce, Washington, DC, p 3-23

Buesa RJ (1987) Growth rate of tropical demersal fishes. Mar Ecol Prog Ser 36:191-199

Chen Y, Jackson AD, Harvey HH (1991) A comparison of Von Bertalanffy and polynomial functions in modelling fish growth data. Can J Fish Aquat Sci 49:1228-1235

Choat JH, Axe LM (in press) Growth and longevity in acanthurid fishes; an analysis of otolith increments. Mar Ecol Prog Ser

Doherty PJ, Fowler AJ (1994) An empirical test of recruitment limitation in coral reef fish. Science 263:935-939

Ferreira BP (1993) Reproduction of the inshore coral trout Plectropomus maculatus (Perciformes: Serranidae) from the central Great Barrier Reef, Australia. J Fish Biol 42 (6) : $831-844$

Ferreira BP, Russ GR (1992) Age, growth and mortality of the inshore coral trout Plectropomus maculatus (Pisces: Serranidael from the central Great Barrier Reef, Australia Aust J Mar Freshwat Res 43:1301-1312

Ferreira BP, Russ GR (1993) Age validation and estimation of growth rate of the coral trout, Plectropomus leopardus (Lacepede 1802) from Lizard Island, Northern Great Barrier Reef. Fish Bull 92:46-57

Fishelson L, Montgomery WL, Myrberg A.A (1987) Biology of surgeonfish Acanthurus nigrofuscus with emphasis on changeover in diet and annual gonadal cycles. Mar Ecol Prog Ser 39:37-47

Fowler AJ (1990) Validation of annual growth increments in the otoliths of a small, tropical coral reef fish. Mar Ecol Prog Ser 64:25-38

Fowler AJ, Doherty PJ (1992) Validation of annual growth increments in the otoliths of two species of damselfish from the southern Great Barrier Reef. Aust J Mar Freshwat Res 43:1057-1068

Hart AM, Klumpp DR (1996) Response of herbivorous fishes to crown-of-thorns starfish Acanthaster planci outbreaks. I. Substratum analysis and feeding ecology of Acanthurus nigrofuscus and Scarus frenatus. Mar Ecol Prog Ser 132: $11-19$

Hart AM, Klumpp DR, Russ GR (1996) Response of herbivorous fishes to crown-of-thorns starfish Acanthaster planci outbreaks. II. Density and biomass of selected species of herbivorous fish and fish-habitat correlations. Mar Ecol Prog Ser 132:21-30

Hoenig JM (1984) Empirical use of longevity data to estimate mortality rates. Fish Bull 81(4):789-794

Itano D (1988) American Samoa bottomtish assessment program. Proc South Pacific Commission Inshore Fisheries Resources Workshop SPC, Noumea. Background Paper 68

This article was submitted to the editor
Jones GP (1990) The importance of recruitment to the dynamics of a coral reef fish population. Ecology 71(5):1691-1698

Jones GP (1991) Postrecruitment processes in the ecology of coral reef fish populations: a multifactorial perspective. In: Sale PF (ed) The ecology of coral reef fishes. Academic Press, Orlando, p 294-328

Kimura DL (1977) Statistical assessment of the age-length key. J Fish Res Bd Can 34(3):317-324

Lassig BR (1983) The effects of a cyclonic storm on coral reef fish assemblages. Environ Biol Fish 9(1):55-63

Lou DC (1992) Validation of annual growth bands in the otolith of tropical parrotfishes (Scarus schlegeli Bleeker). J Fish Biol 41:775-790

McFarlane GA, Beamish RJ (1987) Selection of dosages of oxytetracycline for age validation studies. Can J Fish Aquat Sci 44:905-909

Myrberg AA, Montgomery WL, Fishelson L (1988) The reproductive biology of Acanthurus nigrofuscus (Forskäl) and other surgeonfishes (Fam. Acanthuridae) off Eilat, Israel (Gulf of Aqaba, Red Sea). Ethology 79:31-61

Odense PH, Logan VH (1974) Markıng Atlantic salmon (Salmo salmar) with oxytetracycline. J Fish Res Bd Can 31:348-350

Pauly D (1980) On the interrelationships between natural mortality, growth parameters and mean environmental temperature in 175 fish stocks. J Cons Int Explor Mer 39(3): 175-192

Pauly D (1984) Fish population dynamics in tropical waters: a manual for use with programmable calculators. ICLARM, Manila

Ricker WE (1973) Linear regressions in fishery research. J Fish Res Bd Can 30:409-434

Robertson DR (1983) On the spawnung behaviour and spawning cycles of eight surgeonfishes (Acanthuridae) from the Indo-Pacific. Environ Biol Fish 9(3/4):193-223

Russ GR (1984) Distribution and abundance of herbivorous grazing fishes in the central Great Barrier Reef. II. Patterns of zonation of mid-shelf and outershelf reefs. Mar Ecol Prog Ser 20:35-44

Russ GR, St John J (1988) Diets, growth rates and secondary production of herbivorous coral reef fishes. Proc 6th Int Symp Coral Reefs 2:37-43

Sainsbury K (1980) Effect of individual variability on the Von Bertalanffy growth equation. Can J Fish Aquat Sci 37 : $241-247$

Walsh WJ (1983) Stability of a coral reef fish community following a catastrophic storm. Coral Reefs 2:49-63

Wass RC (1987) Influence of Acanthaster-induced coral kills on fish communities at Fagatele Bay and at Cape Larsen. In: Bırkeland C, Randall RH, Wass RC, Smith BD. Wilkins S (eds) Biological resource assessment of the Fagatele Bay Natonal Marine Sanctuary. NOAA Tech Memo NOS MEMD 3. US Dept Commerce, Washington, DC, p 193-209

Williams D McB (1986) Temporal variation in the structure of reef slope fish communities (central Great Barrier Reef): short-term effects of Acanthaster planci infestation. Mar Ecol Prog Ser 28:157-164

Zar JH (1984) Biostatistical anajysis, 2nd edn. Prentice-Hall, Englewood Cliffs, NJ

Manuscript first received: July 4, 1995

Revised version accepted: December 6, 1995 